\title{
Intersections
}

Canadian Journal of Music

Revue canadienne de musique

\section{Elizabeth Hinkle-Turner. Women Composers and Music Technology in the United States. Burlington, VT: Ashgate Publishing Company, 2006. 301 pp. ISBN 0-7546-0461-6 (hardcover)}

\section{Mark Harris}

Volume 26, numéro 2, 2006

URI : https://id.erudit.org/iderudit/1013231ar

DOI : https://doi.org/10.7202/1013231ar

Aller au sommaire du numéro

Éditeur(s)

Canadian University Music Society / Société de musique des universités canadiennes

ISSN

1911-0146 (imprimé)

1918-512X (numérique)

Découvrir la revue

Citer ce compte rendu

Harris, M. (2006). Compte rendu de [Elizabeth Hinkle-Turner. Women Composers and Music Technology in the United States. Burlington, VT: Ashgate Publishing Company, 2006. 301 pp. ISBN 0-7546-0461-6 (hardcover)]. Intersections, 26(2), 125-128. https://doi.org/10.7202/1013231ar

Copyright @ Canadian University Music Society / Société de musique des universités canadiennes, 2007
Ce document est protégé par la loi sur le droit d'auteur. L'utilisation des services d'Érudit (y compris la reproduction) est assujettie à sa politique d'utilisation que vous pouvez consulter en ligne.

https://apropos.erudit.org/fr/usagers/politique-dutilisation/ 


\section{BOOK REVIEWS/RECENSIONS}

Elizabeth Hinkle-Turner. Women Composers and Music Technology in the United States. Burlington, VT: Ashgate Publishing Company, 2006. 301 pp. ISBN 0-7546-0461-6 (hardcover).

Elizabeth Hinkle-Turner's Women Composers and Music Technology in the United States stands both as an accomplished effort of documentation and as a comprehensive resource guide for anyone interested in contemporary feminist scholarship in American music. This work came about for a range of reasons. To begin, as in many other fields, music and histories of music have more often than not either discriminated against women or ignored them altogether. These instances of erasure have occurred in various ways, whether in scholarly texts of musicology that fail to mention important women in the field or universities that have few to no female composers enrolled as professors in their music departments. However, Hinkle-Turner does point out in her introduction that feminist music research has been growing steadily, and that there are literary sources that no longer omit women. Instead of just focusing on the phenomenon of exclusion, the author sets out to provide something different: an in-depth discussion of over a hundred American female music composers, engineers, performers and professors. She includes biographical information about them, where they studied, where they taught, a listing of each person's pertinent works, and she remarks upon any instruments and technologies used or preferred by each of her subjects. These composers range in style and subject matter from the abstract, such as the musique concrète of Jean Eichelberger Ivey's Pinball (p. 26) or the percussive suit of Laurie Anderson's Drum Dance (p. 222), to the societal relevance of the AIDS epidemic as depicted in Carolyn Bremer's Not A Witness (p. 175), the landmine crisis of Cambodia as documented in Anna Rubin's Landmines (p. 82), or the struggle of a cancer survivor as told by the author herself (p. 194).

Hinkle-Turner intends to demystify the realm of the "avant-garde" by presenting women who create electroacoustic music, film soundtracks and scores, avant-garde operas, video art and performance pieces. As such, she focuses on women who have historically not had the same recognition, fame or financial support as female pop musicians-the imagery of the MTV superstar is absent here. Hinkle-Turner sets the parameters of her research to cover a timeline from the 1930s to the present, and defines her subject range as artists who were either born in the USA or produced the majority of their works on American soil.

The author takes the standpoint of archivist and collector. Her documentation is meticulous and thorough, the appendices rich with extra resources, web- 
sites and catalogues. Much of her research comes from first-hand information, interviews and correspondence. Furthermore, she is a composer, and the author places her own work within the burgeoning lineage of remarkable artists, adding an autobiographical tilt to a specific segment of the text (pp. 193-195). The author's research is extensive, deriving from both first hand and second hand sources and including interviews, letter exchanges and phone conversations between her and some of the book's subjects. In addition, scholarly reviews and journals, newspaper articles, CDs, videos, websites and live performance are also sources of evidence.

At first glance, the text appears to argue that female musicians, composers and innovators are often neglected in the history of music, in academia and in work settings which involve music. Yet Hinkle-Turner makes it clear that a simple dichotomy of men vs. women does not stand up to a reasonable analysis, as the situation is more complex than we are usually led to believe. For example, composers Eve Beglarian and Kitty Brazelton both remark that Columbia University was unfriendly to women in the music field, this discrimination occurring as late as the early 1990s (pp. 144, 146). On the other hand, violinist and software researcher/producer Joan Miller found that while working at MIT and at the Bell Labs, her gender was not an issue (p. 41). If anything, Hinkle-Turner posits that "perhaps the issue isn't so much a difference in gender and numbers but an issue of documentation" (p. 255).

In some instances, the biographies in this text are grouped together according to pertinent universities or institutions and geographical location, such as the West Coast achievements of Mills College and the University of California, or the East Coast metropolis of New York City, a hub for music schools, musicians, composers and techno savants. However, as a whole, the book is organized in a linear historical form, starting out with the sound pioneers of the 1930s, to the rise of electronic music and MIDI, up to the present day, followed by a brief meditation on the future of female musicians and composers.

Elizabeth Hinkle-Turner accomplishes a great feat of documentation and of storytelling in this book. All of the profiled artists receive in-depth analysis of their educations and careers and concise descriptions of their major works, as well as accounts of the life experiences that have influenced their works. HinkleTurner introduces the category of electroacoustic music by recounting the technical and aesthetic practices of the composers, demonstrating that the aforementioned field contains a profusion of different artistic styles. Some of her composer subjects women use recordings of natural or environmental sounds, such as water, animal cries or the soundscape of a forest. Some work with traditional instruments while others invent their own. There are as many artists who deal with unprocessed sounds as there are those who utilize technology to manipulate their work and to create a seemingly endless sound palette. Through these descriptions, Hinkle-Turner lends a voice to women who are often overlooked in traditional electroacoustic criticism. In providing such intimate and revealing details about the making of electroacoustic music, the genre acquires clearer focus and becomes inviting. As a reader, I was left with the desire to seek out some of the works, such as Laurie Spiegel's Queen BEEing, which utilizes 
recordings of bee hives (p. 46), Annea Lockwood's Piano Burning, in which the artist plays a blazing piano where microphones pick up the sounds of burning wood, snapping piano strings and hissing flames (p. 32), or the performances of Laetitia Sonami and her invention "The Lady's Glove", a piece of clothing designed to trigger sounds (p. 91).

The author recognizes that the social/gender issues within these mini-biographies are not uniform. As previously mentioned, Hinkle-Turner does identify the discrimination faced by women in American music schools and business. One cannot deny the prejudice in the situation of Pril Smiley and Alice Shields, two dedicated pioneers at the Columbia Princeton Electronic Music Center, who despite their "considerable technical instruction," were classified by the institution as "clerk" and "science technician II," and when they did eventually become listed as "associate directors," they did not receive any pay increase (p. 21). One might posit that the author could continue to accumulate similar examples so as to paint virtually all music institutions and male composers as misogynist. Yet Hinkle-Turner does not give in to simplistic binaries and discusses women's positive experiences in sound as well; a case in point is audio engineer Susan Rogers, who Hinkle-Turner notes received much positive feedback and mentoring from the male composer superstar Prince (p. 228). The steps of her argument follow the chronological line of the narrative. From decade to decade, HinkleTurner reveals that gender issues in music are complex interactions, rather than just a clear-cut dichotomy.

There are a couple of hidden assumptions in this book. For one, though it is accessible in terms of its bibliographical content and social commentary, some of the technical aspects may be hard to follow for someone who is not well versed in music theory or computer programming. While the author is fair in her judgement for most of the text, there are instances where she does not reexamine claims that could be construed as biased. One example that struck me is in the introduction of the book where Hinkle-Turner states that "for the male composer the finding of role models and the establishment of a close mentor relationship is made easier by the large number of men active in the composition profession" (p. 7). I found this statement sweeping, in that it assumes that all male composers seek out other men as mentors, and it tends to replicate the biological dualisms in academia/musicology that the author is seeking to disarm.

The breadth of the author's work is well supported by evidence. As previously mentioned, Hinkle-Turner conducted many interviews, exchanged personal correspondence, and completed a formidable hunt for second-hand sources. The only instance in which the book fails to be persuasive occurs in one of the final chapters, where the author discusses the current status of women composers in modern music. Though Hinkle-Turner's scope as a researcher is broad, there are some names that are left out. I understand that the author is attempting to focus on artists who have received little attention, and as such she steers clear of mainstream rock stars. Furthermore, I empathize with her reluctance to address female superstars, because more often than not they are creations of male producers, celebrity agents and the press machine. Nevertheless, it seems jarring for Hinkle-Turner to list Oprah Winfrey, Madonna, Roseanne and Dolly 
Parton as examples of successful businesswomen in the entertainment industry (p. 213). Though she does admit that such commercial success in the music business is rare, it seems that the author is actively omitting some topical names from the roster. Why would she mention Oprah and Roseanne, two women who are not musicians, while failing to discuss other artists, admittedly mainstream but nonetheless pertinent to her work because of their sonic experimentation? American born musicians such as Tori Amos and Diamanda Galas are performers as well as producers. The same could be said of Bjork and PJ Harvey, two women who are not American but have both worked out of New York City. It is as though branding these women with the "mainstream pop/rock" label women negates their technical and aesthetic capabilities. Galas is mentioned, but just in passing, which seems odd considering that she has been producing avant-garde and somewhat popular music for voice, piano, tape and electronics for more than three decades.

Overall, the book is well written and inviting. Composers' lived experiences and artistic practices intertwine to create a sonic landscape that is never static. The pieces are described in such a way that left me wanting to find the recordings and Hinkle-Turner does a brilliant job of providing resources for electroacoustic music by women.

Women Composers and Music Technology in the United States exposes a stream of work that is seeking its rightful place in the grand scope of the history of music. Through the author's work, it is evident that these inventions, performances and compositions are significant endeavours within the discourse of electroacoustic music. Hinkle-Turner showcases producers of media that have been overlooked due to their biology and gender. Because both men and women find success and failure in the music realm, Hinkle-Turner suggests in her conclusion that there is not necessarily "a difference in achievement; it is rather a difference in reporting" (p. 255). Because this book is such a great compendium of women composers, it is a testament that if proper documenting is done, then vital histories will be preserved.

MARK HARris 